\title{
Effects of adjuvants on herbicidal action. III. Effects of petroleum and rapeseed oils on diclofop-methyl action on ryegrass
}

\author{
JJ Schott ${ }^{*}$, JL Dufour, C Gauvrit ** \\ INRA BV 1540, Laboratoire de Malherbologie, 21034 Dijon, Cedex, France
}

(Received 18 December 1989; accepted 25 October 1990)

\begin{abstract}
Summary - Petroleum oil, rapeseed oil and its methyl ester derivative enhance efficacy of an Illoxan CE emulsion of diclofop-methyl on ryegrass (Lolium multiflorum Lam) by 65,29 and $57 \%$ respectively. These adjuvants only marginally improve spray retention by plants. The abaxial leaf surface retains more spray than the adaxial surface: $3.4,4.0,7.3$ and 6.9 times at $0,30,60$ and $80^{\circ}$ leaf inclination respectively. Droplet drying was 110 to $150 \%$ accelerated by both the oils and the emulsifier. This was accompanied by an increase in the spread of droplets : 3.7 times with the methyl ester derivative on a surface basis. Diclofop-methyl penetration into ryegrass (adaxial surface) was not affected by the emulsifier; was $210 \%$ increased by rapeseed oil, $310 \%$ by its methyl ester and $500 \%$ by petroleum oil. Diclofop-methyl penetration after $24 \mathrm{~h}$ was $20 \%$ of the applied herbicide on the adaxial surface (poorly wettable), but only $4 \%$ on the abaxial surface (highly wettable). Addition of rapeseed oil methyl ester derivative increased it to 81 and $9 \%$ respectively.
\end{abstract}

diclofop-methyl / petroleum oil / rapeseed oil / droplet spread / penetration

Résumé - Effet d'adjuvants sur l'action herbicide. III. Effets d'huiles minérale et végétale sur l'action du diclofop-méthyl sur le ray-grass. Une huile minérale, une huile végétale (colza), ainsi que son ester méthylique, augmentent l'efficacité du diclofop-méthyl sur ray-grass (Lolium multiflorum Lam) respectivement de 65, 29 et 57\% (fig 1). Ces adjuvants n'améliorent que peu ou pas la rétention de pulvérisation par les plantes (tableaux I, II et IV). La face abaxiale retient davantage de pulvérisation que la face adaxiale :3,4, 4,0, 7,3 et 6,9 fois plus à, respectivement, 0 , 30,60 et $80^{\circ}$ d'inclinaison (tableau III). Le séchage des gouttelettes déposées sur le feuillage est accéléré par les huiles ou l'émulgateur seul (de 110 à 150\%) (fig 2), et leur étalement augmenté (3,7 fois en surface par l'ester méthylique) (fig 3). La pénétration du diclofop-méthyl par la face adaxiale n'est pas affectée par l'émulgateur mais est augmentée de $210 \%$ par l'huile de colza, 310\% par son ester méthylique et $500 \%$ par l'huile minérale (fig 4). En 24 h, $20 \%$ du diclofop-méthyl appliqué pénètre par la face adaxiale (peu mouillable) et seulement $4 \%$ par la face abaxiale (très mouillable). L'addition d'ester d'huile de colza accroît ces valeurs à, respectivement, 81 à $9 \%$ (tableau V).

\section{diclofop-méthyl / huile minérale / huile végétale / étalement de goutte / pénétration}

\section{INTRODUCTION}

In recent years, several reports have shown that crop or petroleum oil as an adjuvant in aqueous formulations can increase the efficacy of postemergence herbicides, eg fluazifop-butyl, haloxyfop-methyl and sethoxydim (Buhler and Burnside, 1984), acifluorfen and sethoxydim (Chen and Penner, 1985), atrazine, cyanazine, bentazon, sethoxydim and diclofop-methyl (Nalewaja,
1986), diclofop-methyl (Ayres, 1987; Bouchet and Beaufreton, 1988), phenmedipham (Parmentier, 1987), sethoxydim, fluazifop-p, quizalofop, haloxyfop and cloproxydim (Barrentine and McWhorter, 1988), fluazifop (Smeda and Putnam, 1989).

The higher efficacy in the presence of oil was attributed to effects on several parameters of herbicidal action: spray retention (Nalewaja, 1986; De Ruiter et al, 1987), droplet spread on leaf sur-

\footnotetext{
* Present address: GEVES, INRA, La Minière, 78280 Guyancourt, France.
}

** Correspondence and reprints. 
face (McWhorter and Barrentine, 1988; Wanamarta et al, 1989; Schott et al, 1990), penetration (Gillepsie et al, 1988; Grafstrom and Nalewaja, 1988; McCall, 1988; Wanamarta et al, 1989; Gauvrit and Dufour, 1990; Schott et al, 1990) as well as translocation (Gillepsie et al, 1988).

Moreover, it is currently under debate as to whether crop oils are comparable with petroleum oils. In particular, among the aforementioned studies, those of Nalewaja (1986), Parmentier (1987), De Ruiter et al (1987), McWhorter and Barrentine (1988), Gillepsie et al (1988) and Schott et al (1990) dealt with seed oils of various origins. Basically, they have the same action as petroleum oils, being equally or more effective with some herbicides, less effective with others. Methylated esters obtained from seed oils usually perform better than the parent oil (Nalewaja, 1986; Schott et al, 1990).

We feel that further investigations are required to obtain a clearer picture on the mode of action of oils. To begin with, we studied the consequences of the addition of petroleum, oil, rapeseed oil and its methyl ester derivative (hereafter referred to as oil ester) on the efficacy of diclofop-methyl on ryegrass (Lolium multiflorum Lam). We then examined the effect of these oils on retention, droplet spread and penetration of diclofop-methyl in ryegrass. Since the two surfaces of ryegrass leaf have different wettability properties (Field and Bishop, 1988), we paid particular attention to this factor.

\section{MATERIALS AND METHODS}

\section{Plant culture}

Ryegrass (Lolium multiflorum Lam cv Adret) seeds were germinated for $4 \mathrm{~d}$ at $25^{\circ} \mathrm{C}$ then sown in a clay loam soil: sand mixture (1:1). Plants were then placed in a growth cabinet at $14 / 9{ }^{\circ} \mathrm{C}(\mathrm{d} /$ night), $14 \mathrm{~h}$ photoperiod and $65 / 95 \%$ relative humidity. All experiments were performed when the third leaf was 1 to $3 \mathrm{~cm}$ long.

\section{Oils}

Petroleum oil was "Base Insecticide d'Eté" from the Esso company (sulfonation index $>92 \%$; viscosity at $40^{\circ} \mathrm{C}: 13 \mathrm{~mm}^{2} \cdot \mathrm{s}^{-1}$ ). Refined rapeseed oil (saponification index: 188-192; iodine index: 112-116; viscosity at

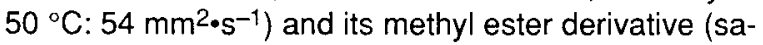
ponification index: 180-190; iodine index: 100-120; viscosity at $50^{\circ} \mathrm{C}: 3.9 \mathrm{~mm}^{2} \cdot \mathrm{s}^{-1}$ ) were obtained from the Robbe company. All 3 oils were prepared with $15 \%$ common emulsifier ( $25 \%$ calcium alkylarylsulfonate, $75 \%$ polyethoxylated nonylphenol BC $616 \mathrm{~mol}$ ethylene oxide). As petroleum oil, rapeseed oil and oil ester are not miscible in Illoxan CE emulsions, it is implicit that the emulsifier is present whenever they are used. It must be stressed that our oil preparations differed from the corresponding commercial preparations since the common emulsifier we used was different from the emulsifier systems present in the marketed products.

\section{Diclofop-methyl efficacy on ryegrass}

Diclofop-methyl was applied as an Illoxan CE emulsion by means of an indoor sprayer consisting of a movable boom with 2 blue "Albuz" $110^{\circ}$ nozzles positioned $50 \mathrm{~cm}$ apart. Plants were placed $48 \mathrm{~cm}$ under the nozzles and were sprayed at $150 \mathrm{~g}^{\circ} \mathrm{ha}^{-1}$ diclofopmethyl, $150 \mathrm{l} \cdot \mathrm{ha}^{-1}$. Oils and emulsifer additions were 0.33 and $0.05 \%(\mathrm{v} / \mathrm{v})$ respectively. Nine replications with 8 plants each were carried out for each treatment and after $20 \mathrm{~d}$ the shoots were cut off at ground level and placed at $80^{\circ} \mathrm{C}$ for $24 \mathrm{~h}$ for dry weight determination. Treatments with Illoxan CE emulsion without any adjuvant will be referred to as Illoxan spray.

\section{Retention measurements}

The sprays contained $0.01 \%$ fluorescein as in Richardson's experiments (1984). After the spray had dried on the foliage, the plants were cut off at ground level and shaken for $30 \mathrm{~s}$ in $50 \mathrm{ml} 5 \mathrm{mmol}^{-1} \mathrm{NaOH}$. Readings were made in a Jobin and Yvon 3-D spectrofluorimeter at $490 / 510 \mathrm{~nm}$. Plants were then placed at $80^{\circ} \mathrm{C}$ for 24 $h$ and dry matter weighed. Six replications with 8 plants each were carried out for each treatment.

To study the influence of leaf inclination on retention, $3 \times 10$ fragments $(11 \mathrm{~cm}$ long) of the second leaf were placed $1.5 \mathrm{~cm}$ apart on a filter paper which was placed at the desired inclination $\left(0,30,60\right.$ and $\left.80^{\circ}\right)$ under the sprayer.

To determine whether oil modifies spray distribution on the plant, a retention experiment was conducted in which, following treatment, plants were cut into the following parts: tiller, leaf sheathes, third leaf, and the first and second leaves portions were distinguished according to their abaxial or adaxial exposure towards the spray (at this stage ryegrass leaves are often twisted and present their abaxial and adaxial surfaces alternatively).

\section{Contact angle}

Two- $\mu$ l droplets were deposited by means of a Hamilton microsyringe on the leaf surface. Angles were measured $30 \mathrm{~s}$ after deposition with a Wild binocular microscope equipped with a goniometric device. Five 
measurements were performed for each condition. Temperature was $22^{\circ} \mathrm{C}$ and relative humidity $41-46 \%$.

\section{Drop evaporation and spread}

Three 2- $\mu$ droplets were deposited on the adaxial surface of a detached second leaf and weight evolution was monitored with $0.03 \mathrm{mg}$ accuracy. To determine droplet spread, photographs were taken through a binocular microscope and image analysis used to measure droplet area. The experiments were conducted at $22^{\circ} \mathrm{C}$ and $48-52 \%$ relative humidity.

\section{Diclofop-methyl penetration}

Ring ${ }^{14} \mathrm{C}$ labelled diclofop-methyl $\left(257 \mathrm{MBq} \cdot \mathrm{mmol}^{-1}\right.$, $98.5 \%$ radiochemical purity) was dissolved in ethanol. An aliquot containing the desired radioactivity was deposited at the bottom of a conical tube and the ethanol was evaporated to dryness. An aqueous emulsion of IIloxan CE was added, at a concentration corresponding to a $150 \mathrm{~g} \cdot \mathrm{ha}^{-1}$ diclofop-methyl, $150 \mathrm{l} \cdot \mathrm{ha}^{-1}$ treatment. Gentle shaking for $2 \mathrm{~h}$ interspersed with two 10-s sonication spells redissolved radiolabelled diclofop-methyl. Radioactivity of the preparation was $16.7 \mathrm{~Bq} \cdot \mu^{-1}$ and cold herbicide was $99.6 \%$ of total herbicide. When oils were added, their concentration was $0.33 \%(\mathrm{v} / \mathrm{v})$.

Four $0.5-\mu$ ldroplets of the above emulsion were deposited on the upper third of the second leat. Penetration was determined 1 and $3 \mathrm{~d}$ after treatment. Each measurement was carried out on 5 plants from the same pot and the experiment was conducted with 3 replicates. Absorption was evaluated by washing the treated area of each leaf with $1 \mathrm{ml}$ acetone then $1 \mathrm{ml}$ chloroform. Washes were combined and evaporated to dryness. Ethanol was added to dissolve diclofopmethyl which was counted in Dynagel (JT Baker Chemicals, The Netherlands) by scintillation counting. Leaves were dried $\left(24 \mathrm{~h}, 80^{\circ} \mathrm{C}\right)$ and combusted in an oxidizer for radioactivity assessment.

\section{Statistics}

Data were submitted to analysis of variance and means were compared using the Newman and Keuls test at the 5\% level (Cochran and Cox, 1968). In the tables and figures data marked with the same letters do not differ significantly.

\section{RESULTS}

\section{Diclofop-methyl efficacy on ryegrass}

The effect of petrolenum oil, rapeseed oil and the oil ester on diclofop-methyl efficacy on ryegrass is shown in figure 1. Under our experimental conditions $150 \mathrm{~g} \cdot \mathrm{ha}^{-1}$ diclofop-methyl reduced growth by $49 \%$ on a dry matter basis. All adjuvants significantly enhanced diclofop-methyl action, the most active being petroleum oil and the oil ester which brought growth inhibition up to 81 and $77 \%$ respectively. The emulsifier added alone increased diclofop-methyl efficacy to the same extent as rapeseed oil.

\section{Retention}

At the stage studied, ryegrass retained $222 \mu \mathrm{lll}$ loxan spray per $g$ dry matter. Addition of oils increased retention but only with petroleum oil was it significant: $+20 \%$ (table I).

The presence of the oil ester in the sprayed emulsion did not modify its distribution on the plant (table II). As expected, the wettable abaxial leaf surface retained more spray than the adaxial surface (about 4 times) and it accounted for almost two thirds of total retention.

Retention greatly varied with leaf inclination (table III): from 0 to $80^{\circ}$ it decreased by $82 \%$ on the adaxial leaf surface and by $63 \%$ on the abaxial surface.

\section{Contact angle}

On the abaxial leaf surface Illoxan emulsion droplets spread in a few seconds and no contact angle could be measured. On the adaxial leaf surface contact angle measured $30 \mathrm{~s}$ after deposition were greatly decreased by all 3 oils and even more by the emulsifer alone (table IV).

Table I. Effect of oil adjuvants on spray retention by ryegrass. Abbreviations: ILL, Illoxan CE emulsion; EM, $P O, R O$ and $O E$, Illoxan CE emulsion combined with the emulsifier, petroleum oil, rapeseed oil and the rapeseed oil methyl ester derivative, respectively.

Retention

$\left(\mu \log { }^{-1}\right)$

$\begin{array}{ll}\text { ILL } & 222^{b} \\ \text { EM } & 544^{a b} \\ \text { PO } & 266^{a} \\ \text { RO } & 250^{a b} \\ \text { OE } & 238^{a b}\end{array}$




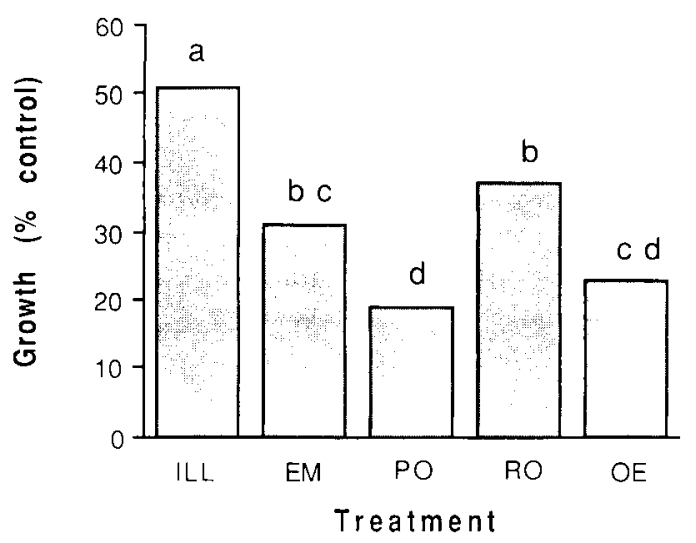

Fig 1. Effect of oil adjuvants on diclofop-methyl efficacy on ryegrass. Data are expressed as \% control growth $(1.77 \mathrm{~g}$ dry matter). Abbreviations: ILL, Illoxan CE emulsion; EM, PO, $R O$ and OE, Illoxan CE emulsion combined with the emulsifier, petroleum oil, rapeseed oil and the rapeseed oil methyl ester derivative, respectively.

\section{Droplet evaporation and spread}

Droplet evaporation could be accurately monitored by weighing the detached leaf on which 3 $2-\mu l$ droplets had been deposited (fig 2). Weight loss from the leaf was linear throughout the experiment. Illoxan emulsion deposits dried in 2530 min whereas in the presence of rapeseed oil or the oil ester it took less than $15 \mathrm{~min}$ and around 10 min with petroleum oil. The emulsifier accelerated desiccation to the same extent as rapeseed oil and the oil ester.

Figure 3 shows that Illoxan emulsion droplets evaporated without spreading on the adaxial surface. Hence, contact angle evolution was solely due to evaporation. By contrast, when the oil ester was present in the emulsion, spread occurred and once desiccation was completed, the depos-

Table II. Effect of the methylated derivative of rapeseed oil on spray repartition on ryegrass plants. Partition of the plants is detailed in the text. "Abaxial" and "Adaxial" refer to spray exposure on the first and second leaves. Figures in brackets are retention in $\%$ of total plant. ILL, OE: see table I.

\section{Retention $\left(\mu \mathrm{l} \cdot \mathrm{g}^{-1}, \%\right)$}

ILL $O E$

\begin{tabular}{lllll} 
Tiller & $356^{\mathrm{a}}$ & $(3.8)$ & $350^{\mathrm{a}}$ & $(3.9)$ \\
Leaf sheathes & $97 \mathrm{~b}^{\mathrm{b}}$ & $(10.6)$ & $103^{\mathrm{b}}$ & $(11.2)$ \\
Third leaf & $184^{\mathrm{c}}$ & $(12.2)$ & $195^{\mathrm{c}}$ & $(13.4)$ \\
Adaxial & $108^{\mathrm{d}}$ & $(8.0)$ & $128^{\mathrm{d}}$ & $(8.7)$ \\
Abaxial & $406^{\mathrm{e}}$ & $(65.4)$ & $402^{\mathrm{e}}$ & $(62.8)$ \\
Plant (total) & $237^{\mathrm{f}}$ & $(100.0)$ & $242^{\mathrm{f}}$ & $(100.0)$ \\
\hline
\end{tabular}

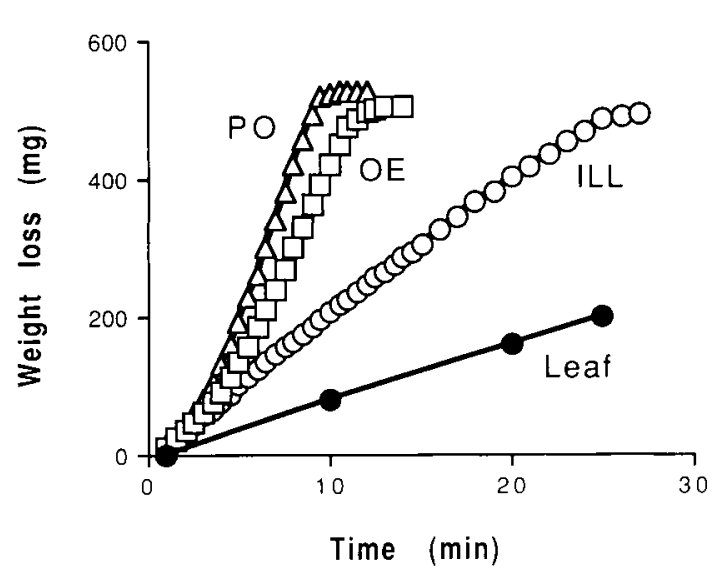

Fig 2. Effect of oil adjuvants on the evaporation kinetics of diclofop-methyl droplets. Data are expressed in weight loss $(\mathrm{mg})$ of the leaf on which droplets were deposited. Leaf: leaf without deposit. Other abbreviations are defined in figure 1. This is a typical experiment taken from 5 with similar results.

it surface had been multiplied by 3.7. In this case, contact angle decrease was faster.

On the abaxial leaf surface spread occurred even in the absence of the oil ester but was so rapid that it had taken place before measurements could be made. Its extent was the same with or without the oil ester (data not shown).

\section{Penetration}

Diclofop-methyl penetration into ryegrass second leaf differed according to which surface radiolabelled herbicide was deposited on. Penetration through the abaxial surface was low whereas it was 5 times more important through the adaxial surface (table V). Addition of the oil ester dramatically increased penetration which was about quadrupled on the adaxial surface and more than doubled on the abaxial surface.

Table III. Spray retention by detached leaves as a function of inclination.

\begin{tabular}{ccc}
\multicolumn{3}{c}{ Retention $\left(\mu /{ }^{\circ} g^{-1}\right)$} \\
Abaxial & Adaxial & Ratio \\
surface & surface &
\end{tabular}

Leaf inclination $\left({ }^{\circ}\right)$

$\begin{array}{rrrr}0 & 693 & 204 & 3.4 \\ 30 & 586 & 147 & 4.0 \\ 60 & 411 & 56 & 7.3 \\ 80 & 255 & 37 & 6.9\end{array}$


Table IV. Effect of oil adjuvants on the contact angle of diclofop-methyl droplets deposited on the adaxial surface of ryegrass second leaf. Abbrevations: see table 1.

\section{Contact angle $\left(^{\circ}\right)$}

$\begin{array}{ll}\text { ILL } & 88^{a} \\ \text { EM } & 40^{c} \\ \text { PO } & 55^{b} \\ \text { RO } & 58^{b} \\ \text { OE } & 60^{b}\end{array}$

All 3 oils promoted diclofop-methyl penetration into ryegrass. This is shown in figure 4: on the abaxial surface, diclofop-methyl penetration from Illoxan emulsion was only $3 \%$ after $3 \mathrm{~d}$; the emulsifier had no significant effect, whereas rapeseed oil increased it to $9 \%$, the oil ester to $12 \%$ and petroleum oil to $17 \%$.

\section{DISCUSSION}

\section{Diclofop-methyl efficacy on ryegrass}

Our results confirm the well-known fact that oil can increase the efficacy of postemergence herbicides. Petroleum oil was significantly more active than rapeseed oil in promoting diclofopmethyl action. Nalewaja (1986) found a similar result using sunflower or linseed oil (the lower performance of soybean oil was not significant).

From the few studies published, it emerges that whether petroleum or seed oils give better

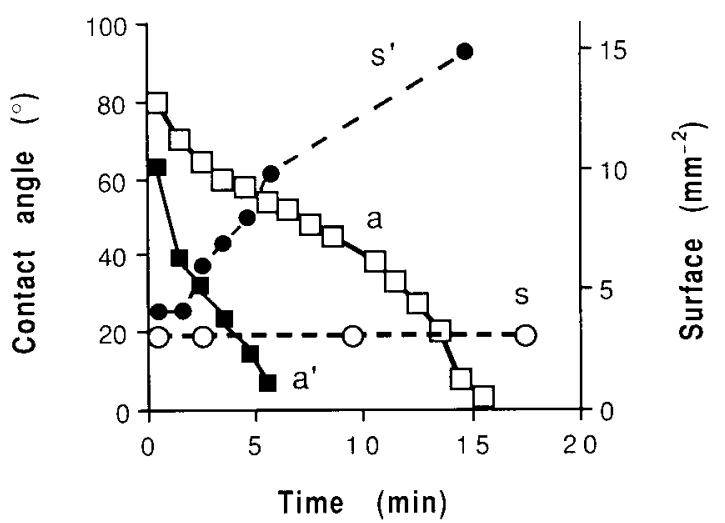

Fig 3. Effect of methylated derivative of rapeseed oil on contact angle and deposit surface evolutions. a, s: angle and surface for an Illoxan CE emulsion; $a^{\prime}, s^{\prime}$ : angle and surface for an Illoxan CE emulsion combined with the oil ester. This is a typical experiment taken from 3 with similar results.
Table V. Effect of leaf surface and methylated rapeseed oil derivative on diclofop-methyl penetration into ryegrass second leaf. Penetration is expressed in \% applied radioactivity. ILL, OE: see table $\mathrm{I}$.

\section{Penetration (\%)}

$$
\text { ILL OE }
$$

$\begin{array}{lrr}\text { Abaxial surface } & 4^{a} & 9^{b} \\ \text { Adaxial surface } & 20^{c} & 81^{d}\end{array}$

results depends on the herbicide considered. It seems that petroleum oils are better with diclofop-methyl (Nalewaja, 1986, and the present study), bentazon (Nalewaja, 1986; Wanamarta et al, 1989) and fenoxaprop, fluazifop and haloxyfop (Nalewaja, 1986). Seed oils perform better with glyphosate (De Ruiter et al, 1987) and cyanazine (Nalewaja, 1986), whereas they are equally effective as petroleum oils with phenmedipham (Parmentier, 1987), sethoxydim (Nalewaja, 1986; Wanarmata et al, 1989), atrazine, acifluorfen and clopropoxydim (Nalewaja, 1986).

In our experiments the action of the oil ester was similar to that of petroleum oil. Nalewaja (1986) found the same with soybean or sunflower methylated oils and herbicides such as diclofop-methyl, sethoxydim, clopropoxydim, fluazifop, fenoxaprop and haloxyfop. Hence, these derivatives appear to be promising adjuvants.

A last point worth noting is that under our conditions, rapeseed oil and the emulsifier brought about the same increase in diclofop-methyl effi-

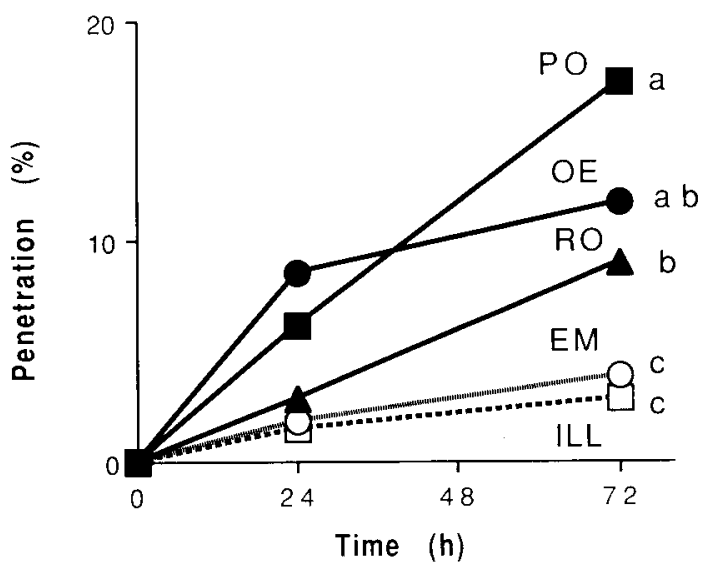

Fig 4. Effect of oil adjuvants on diclofop-methyl penetration through the adaxial surface of ryegrass second leaf. Results are expressed in \% penetration of applied radioactivity. Abbreviations: see figure 1 . 
cacy. As rapeseed oil contained the emulsifier, one can question the action of rapeseed oil perse.

\section{Retention}

Field and Bishop (1988) have shown that the 2 leaf surfaces of ryegrass (Lolium perenne $L$ ) differ greatly in their properties. They found contact angles of 118 and $36^{\circ}$ for formulated glyphosate droplets on the adaxial and abaxial surfaces respectively, which shows that the abaxial surface is by far the most wettable. Moreover, at 3rd leaf appearance, the 2nd leaf begins to twist and exposes its abaxial face to the spray. Hence, ryegrass morphology can be expected to influence retention and we felt that it was important to see whether we could observe the same wettability difference on Lolium multiflorum before assessing the effect of oil on retention by this species.

Table II shows that almost two thirds of the spray was retained by the abaxial surfaces exposed to it. Hence, they largely determine retention by the whole plant. Adaxial surfaces accounted for only $8 \%$ of total retention and the sheathes - the nearest parts to the meristem for $11 \%$. Retention per dry weight unit was 3.8 times greater on abaxial surfaces.

As it is difficult on a twisted ryegrass leaf to separate unambiguously abaxial from adaxial exposures to the spray, we also studied retention on detached leaves. At low inclination $\left(0-30^{\circ}\right)$, the retention ratio between the two surfaces lay between 3.4 and 4.0 and went up to 7.3 and 6.9 as angle increased to 60 and $80^{\circ}$. These results also show the dramatic influence of inclination on retention: at $0^{\circ}$ the abaxial surface retained $693 \mu \mathrm{l}$ spray per $\mathrm{g}$ dry matter and $255 \mu \mathrm{l}$ at $80^{\circ}$, the decrease being proportionally greater for the adaxial surface: 204 and $37 \mu \mathrm{l}^{-\mathrm{g}^{-1}}$, respectively.

These results illustrate the importance of morphology for spray retention by ryegrass. At the 2leaf stage foliar parts are upright, adaxial surfaces are exposed to the spray and retention is expected to be low. As the third leaf develops, the second leaf bends and twists. As a consequence, it exposes a significant portion of the abaxial (wettable) surface in an almost horizontal position to the spray. It follows that at this stage retention is high, as exemplified by our results, and can be compared to that of dicotyledonous plants such as Chamomilla reticuta and Solanum nigrum (De Ruiter and Uffing, 1988).

Spray retention was not greatly affected by oils: only with petroleum oil could we observe a significant - although limited $(20 \%)$ - increase (table I). Two explanations for this lack of effect can be put forward. Firstly, ryegrass is a wettable plant: at 500 I spray per ha it retained more than $500 \mu \mathrm{l}$ per g dry matter (Gauvrit and Dufour, 1990). It is known that adjuvants can increase spray retention markedly on poorly wettable plants but only marginally on wettable ones (Blackman et al, 1958; De Ruiter and Uffing, 1988). Secondly, the surface tension of Illoxan emulsions is close to $30 \mathrm{mN} \cdot \mathrm{m}^{-1}$ and is not modified by any of the oils we used (data not shown). Since surface tension plays a predominant role in spray retention (Anderson et al, 1987) this explains why oil - actually oil plus emulsifier - addition does not affect the retention of Illoxan emulsions.

Since diclofop-methyl is all the more phytotoxic as it is applied nearer to the leaf basis (Walter et al, 1990), it was important to see whether oils could affect emulsion distribution on the plant. Table II shows that the oil ester had no effect, in particular, retention was not significantly increased on the non-wettable portions of the leaf.

It can be concluded from the above experiments that the reason for the increased diclofopmethyl phytotoxicity in the presence of oils does not lie in retention phenomena.

\section{Contact angle, drop evaporation and spread}

After deposition, the contact angle of the droplets began to decrease, and we had thus to measure them after a well defined time; for practical reasons we chose $30 \mathrm{~s}$.

Contact angle on the adaxial surface was greatly affected by the oils studied (table IV). Emulsifier alone was even more active, showing that it is responsible, at least partly, for the decrease in contact angle. Its action can be viewed as a lowering of surface tension between the liquid phase of the drop and the cuticule, allowing spread. A reason for the greater efficiency of the emulsifier applied alone might be that, as it is not involved in interactions with oil, more of it is available to interact with cuticle.

There seems to be a discrepancy between the observed effects of oils on contact angles and their lack of effect on retention. However, it might be only apparent for 3 reasons. Firstly, in our case, the addition of oils did not decrease surface tension in llloxan emulsions - which is already low. Secondly, the angles were measured 
$30 \mathrm{~s}$ after deposition, in the course of a relatively fast decrease and with our method we had no access to the value of the contact angle immediately following deposition. Figure 3 shows that the contact angle difference between Illoxan emulsion droplets with and without oil increased with time. We can therefore suppose that the difference following deposition is not so important as $30 \mathrm{~s}$ after (visual qualitative estimations confirm this view). Finally, spray retention results from phenomena taking place in a few ms, whereas we measured contact angles on a time scale several orders of magnitude higher. In this line, Anderson et al (1987) noted that retention and spread relate to different parameters, namely, dynamic and equilibrium surface tension respectively, and one can alter them independently.

As our experiments were conducted in a relatively dry atmosphere ( 41 to $52 \%$ relative humidity), droplets evaporated rapidly. This process was accelerated by oils (fig 2). At the same time, and only in the presence of oil, did the droplets spread (fig 3). As spreading increases drop-leaf and drop-air contact surfaces, it enhances thermic and matter transfers and, as a consequence, droplet evaporation.

\section{Penetration}

As almost two thirds of the spray is retained on the abaxial leaf surfaces, we decided in a first step to study penetration through this. Figure 4 shows that diclofop-methyl penetration is quite low through this surface since after $3 \mathrm{~d}$ it amounted to only $3 \%$ of the applied ${ }^{14} \mathrm{C}$ diclofop-methyl. The emulsifier had no significant effect, whereas all 3 oils promoted penetration. Petroleum oil performed the best and increased penetration to $17 \%$, followed by the oil ester (12\%) and rapeseed oil $(9 \%)$. Increased penetration in the presence of oil had already been observed for herbicides such as fluazifop (Grafstrom and Nalewaja, 1988), haloxyfop (McCall, 1988), sethoxydim and bentazon (Wanamarta et al, 1988) and diclofopmethyl (Gillepsie and Nalewaja, 1989; Gauvrit and Dufour, 1990; Schott et al, 1990). This action has not yet been clearly explained, all the more as the interactions between oil and the cuticule components are poorly understood.

Since the abaxial and adaxial leaf surfaces differ greatly, it was of interest to observe the consequence on diclofop-methy I penetration. Ta- ble $V$ shows that it was better ( 5 times in this experiment) through the poorly wettable adaxial surface than through the wettable abaxial surface. According to Field and Bishop (1988) on Lolium perenne, the first one presents dense deposits of crystalline wax whereas the latter is covered with amorphous wax sheet. This well explains the difference in wetting and is in agreement with results obtained by Holloway and Silcox (1985) who studied non-ionic surfactant penetration into plants. They found that it was faster into waxy leaves such as rape (Brassica napus $\mathrm{L}$ ) and pea (Pisum sativum $\mathrm{L}$ ) leaves which possess microcrystalline wax deposits on their surface.

The oil ester promoted diclofop-methyl penetration to different extents according to the leaf surface: about twice on the abaxial and about 4 times on the adaxial surface (table V). Spread increases contact surface and hence can be thought to also increase penetration. However, it cannot explain the improved penetration through the abaxial surface since the llloxan emulsion droplets spread to the same extent with or without the oil ester. Hence, in this case, the oil ester seems to have a direct effect on diclofop-methyl penetration. By contrast, the spread which occurred on the adaxial surface may play a role in the increase in penetration since here, absorption was increased 4 (instead of 2) times by the oil ester. The relationship between spread and penetration is not clear. For example, Wanamarta et al (1989) found no relationship between sethoxydim droplet spread and absorption, whereas some, however slight, could be detected with bentazon.

Hence, the higher diclofop-methyl efficacy on ryegrass in the presence of oils could be attributed to better penetration into the plant and perhaps also to droplet spread on the leaf surface.

\section{ACKNOWLEDGMENTS}

This work is part of the project "Adjuvants for optimization of pesticide utilization" initiated by ACTA, France. We wish to thank F Severin (ACTA) for stimulating discussions, F Darchy (Rhône Poulenc Agrochimie, France) for the preparation of the oils and the emulsifier, and for surface tension measurements, ESSO Co and Robbe Co, France, for the supply of oils, Hoechst Co, Germany, for the generous gift of radiolabelled diclofop-methyl and ND Polge for his help during the preparation of the manuscript. 


\section{REFERENCES}

Anderson NH, Hall DJ, Seaman D (1987) Spray retention: effects of surfactants and plant species. Asp Appl Biol 14, 233-243

Ayres $P$ (1987) Use of adjuvants to improve control of black-grass (Alopecurus myosuroides Huds) by diclofop-methyl. Weed Res 27, 195-205

Barrentine WL, McWhorter CG (1988) Johnsongrass (Sorghum halepense) control with herbicides in oil diluents. Weed Sci 36, 102-110

Blackman GE, Bruce RS, Holly K (1958) Studies in the principles of toxicity. $V$. Interrelationships between specific differences in spray retention and selective phytotoxicity. J Exp Bot 9, 175-205

Bouchet C, Beaufreton C (1988) Incidence de l'utilisation d'adjuvants sur l'efficacité de deux herbicides. EWRS Symp Wageningen. Factors affecting herbicidal activity and selectivity, 375-380

Buhler DD, Burnside OC (1984) Effect of application factors on post-emergence phytotoxicity of fluazifop-butyl, haloxyfop-methyl, and sethoxydim. Weed Sci 32, 574-583

Chen YZ, Penner D (1985) Combination effects of acifluorfen with crop oil concentrates and postemergence grass herbicides. Weed Sci 33, 91-95

Cochran WG, Cox GM (1968) Experimental Designs. John Wiley \& Sons, New York, 2nd edn, 76-78

De Ruiter H, Uffing AJM (1988) The influence of surfactants and plant species on the retention of spray solutions. EWRS Symp Wageningen, Factors affecting herbicidal activity and selectivity, 163-168

De Ruiter H, Hoekstra JR, Uffing AJM (1987) The influence of different adjuvants on the phytotoxicity of glyphosate and fluazifop-p-butyl. Meded Fac Landbouwwet Rijksuniv Gent 52(3b), 1217-1224

Field RJ, Bishop NG (1988) Promotion of stomatal infiltration of glyphosate by an organosilicone surfactant reduces the critical rainfall period. Pestic Sci $24,55-62$

Gauvrit C, Dufour JL (1990) Effet d'un mélange d'adjuvants sur les paramètres d'efficacité du diclofop-methyl. 14th COLUMA Conf, Versailles, 23-24 January, 137-145
Gillepsie GR, Nalewaja JD (1989) Influence of 2,4-D and MCPA formulations and oil on diclofop phytotoxicity. Weed Sci 37, 380-384

Gillepsie GR, Skrzypczak GA, Nalewaja JD (1988) Absorption and translocation of CGA-82725 with additives. Weed Sci 36, 282-285

Grafstrom LD Jr, Nalewaja JD (1988) Uptake and translocation of fluazifop in green foxtail (Setaria viridis). Weed Sci 36, 153-158

Holloway PJ, Silcox D (1985) Behaviour of three nonionic surfactants following foliar application. Proc $B$ Crop Prot Conf Weeds 3C-5, 297-302

McCall PJ (1988) Effect of chemical structure, temperature, crop oil concentrate, and bentazon on the behavior of haloxyfop in yellow foxtail (Setaria glauca) - a quantitative modeling approach. Weed Sci 36, 424-435

McWhorter CG, Barrentine WL (1988) Spread of paraffinic oil on leaf surfaces on johnsongrass (Sorghum halepense). Weed Sci 36, 111-117

Nalewaja JD (1986) Seed oils with herbicides. Meded Fac Landbouwwet Rijksuniv Gent 51/2a, 301-310

Parmentier J (1987) Huile adjuvante sur base végétale dans le traitement herbicide de la betterave. Meded Fac Landbouwwet Rijksuniv Gent 52(2b), 731-742

Richardson RG (1984) Fluorescent tracer technique for measuring total herbicide deposits on plants. Austr Weeds 3, 123-124

Schott JJ, Dufour JL, Gauvrit C (1990) Effets d'huiles sur les paramètres d'efficacité du diclofop-methyl appliqué sur raygrass. 14th COLUMA Conf, Versailles, 23-24 January, 147-154

Smeda RJ, Putnam AR (1989) Effect of adjuvant concentration and carrier volume on large crabgrass (Digitaria sanguinalis) control with fluazifop. Weed Technol 3, 105-109

Walter H, Koch W, Mueller F (1990) Einfluss des Applikationsortes auf die Penetration und Translocation von Diclofop-methyl bei Flughafer (Avena fatua L). Weed Res 20, 325-331

Wanamarta G, Penner D, Kells JJ (1989) Identification of efficacious adjuvants for sethoxydim and bentazon. Weed Technol 3, 60-66 